\title{
Pelatihan Manajemen Laktasi untuk Ibu Hamil dan Ibu Menyusui: Upaya Optimalisasi Tumbuh Kembang Anak
}

\author{
Qodri Santosa ${ }^{1}$, Miko Ferrine' ${ }^{2}$, Muhammad Fakih ${ }^{3}$, Alfi Muntafiah ${ }^{4}$ \\ 1,2,3,4 Universitas Jenderal Soedirman
}

\begin{tabular}{|c|c|}
\hline Article History & ABSTRACT \\
\hline \multirow[t]{2}{*}{$\begin{array}{l}\text { Received 26.11.2018 } \\
\text { Received in revised form } \\
20.03 .2019 \\
\text { Accepted 01.04.2019 } \\
\text { Available online 10.04.2019 }\end{array}$} & $\begin{array}{l}\text { LACTATION MANAGEMENT TRAINING FOR PREGNANT WOMEN } \\
\text { AND BREASTFEEDING MOTHERS: EFFORTS TO OPTIMIZE CHILD } \\
\text { GROWTH. The key person for making quality generation lies on mother, } \\
\text { through breast milk. Breastfeeding, besides providing the best nutrition for } \\
\text { optimal baby growth and development, it is also a form of love to a baby. } \\
\text { Ironically, not all mothers realize and many mothers do not breastfeed their } \\
\text { babies exclusively. The low level of knowledge and working mothers is often } \\
\text { an obstacle for mothers to give exclusive breastfeeding. In Indonesia, almost } \\
9 \text { of } 10 \text { mothers give breast milk, but only } 49.8 \% \text { give exclusive breastfeeding } \\
\text { for } 6 \text { months. Lactation management health promotion activities are carried } \\
\text { out in accordance with WHO recommendations and the Indonesian } \\
\text { government in promoting breastfeeding, especially increasing the } \\
\text { achievement of the rate of early breastfeeding initiation and exclusive } \\
\text { breastfeeding. The activities carried out using several methods: counseling, } \\
\text { demonstration, video and discussion. We found that } 54.1 \% \text { of participants } \\
\text { gave exclusive breastfeeding for } 6 \text { months, } 27 \% \text { for } 4 \text { months, and others } 2-3 \\
\text { months. Wilcoxon Rank Test showed a significant difference (p }=0,000 \text { ) } \\
\text { between the score of pre-test and post-test, with a mean pre-test of } 49.02 \pm \\
\text { 19.74, and a mean post-test of } 68.53 \pm 20.00 \text {. Conclution: This activity increased } \\
\text { participants' knowledge regarding lactation management. }\end{array}$ \\
\hline & $\begin{array}{l}\text { Keywords: Exclusive Breastfeeding, Growth and Development, Lactation } \\
\text { Management. }\end{array}$ \\
\hline
\end{tabular}

DOI: $10.30653 / 002.201941 .94$

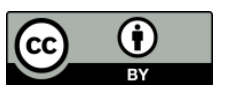

This is an open access article distributed under the terms of the Creative Commons Attribution 4.0 International License, which permits unrestricted use, distribution, and reproduction in any medium, provided the original work is properly cited. (c) 2019 Qodri Santosa, Miko Ferrine, Muhammad Fakih, Alfi Muntafiah.

\section{PENDAHULUAN}

Kemajuan suatu bangsa sangat ditentukan oleh sumber daya manusia (SDM) yang berkualitas, secara fisik dan spiritual. Kunci utama mencetak generasi tersebut terletak pada tokoh ibu. Sejak di dalam kandungan hingga masa penyapihan, ibu harus memberikan asuhan terbaik bagi anaknya termasuk diantaranya dalam hal pemberian air

${ }^{1}$ Corresponding author: Departemen Ilmu Kesehatan Anak Fakultas Kedokteran UNSOED/ RS Margono Soekarjo, Jln. Dr. Gumbreg No. 1 Purwokerto; Email: qodrisantosa@gmail.com 
susu ibu (ASI). Pemberian ASI merupakan wujud kasih sayang ibu terhadap sang buah hati. ASI merupakan makanan bayi terbaik dengan segala kelebihannya, yang tidak dapat tergantikan. ASI mengandung semua nutrisi penting yang diperlukan bayi untuk tumbuh kembangnya (Besar et al., 2008). Lemak, protein, karbohidrat, vitamin, mineral, enzim, dan hormon yang terdapat dalam ASI tidak dapat digantikan oleh susu buatan industri (Perinasia, 2007; Fahriani et al., 2014). ASI mengandung zat antibodi seperti lisozim, laktoferin, dan imunoglobulin A sekretoris (SigA) yang melindungi anak dari infeksi (Irwandi et al., 2018). ASI juga dapat mengurangi kemungkinan menderita gangguan kesehatan di kemudian hari seperti obesitas, diabetes, dan asma (Suradi, 2007; Besar, 2008; WHO, 2014). Adanya faktor protektif dan nutrien yang penting dalam ASI, menyusui juga dapat menciptakan ikatan psikologis dan kasih sayang yang kuat antara ibu dan bayi. Menyusui akan mempererat ikatan antara ibu dan anak (Perinasia, 2007; Permatasari, 2012).

Para ahli menyarankan agar ibu menyusui bayinya selama 6 bulan sejak kelahiran yang dikenal dengan istilah ASI eksklusif (Hegar, 2010). ASI eksklusif memiliki kontribusi besar terhadap tumbuh kembang dan daya tahan tubuh anak. Anak yang diberi ASI eksklusif akan tumbuh dan berkembang secara optimal dan tidak mudah sakit (IDAI, 2009). Kajian global "The Lancet Breastfeeding Series" 2016 telah membuktikan bahwa menyusui eksklusif menurunkan angka kematian karena infeksi sebanyak $88 \%$ pada bayi berusia kurang dari 3 bulan. ASI eksklusif berkontribusi dalam menurunkan risiko obesitas dan penyakit kronis (Perinasia, 2007).

UNICEF (2013) dan WHO (2005) mengemukakan bahwa penyelamat hidup anak yang paling murah dan efektif dalam sejarah kesehatan manusia yaitu menyusui. Menyusui merupakan langkah pertama bagi seorang manusia untuk mendapatkan kehidupan yang sehat dan sejahtera. Ironisnya, tidak semua orang mengetahui hal ini, hanya kurang dari setengah dari anak di dunia yang dapat menikmati kesempatan emas ini (Wattimena et al., 2015). Di beberapa negara maju dan berkembang termasuk Indonesia, banyak ibu bekerja yang tidak menyusui secara eksklusif. Di Indonesia, hampir 9 dari 10 ibu pernah memberikan ASI, namun hanya 49,8\% yang memberikan ASI secara eksklusif selama 6 bulan sesuai rekomendasi WHO. Beberapa negara termasuk Indonesia, Afrika Selatan, Nigeria, dan Tunesia, dilaporkan mengalami penurunan dalam angka ASI eksklusif. Promosi kesehatan (promkes) untuk menyusui cukup efektif di beberapa negara. Kambodia, yang pada tahun 2000 hanya 11,7\% ibu yang berhasil menyusui lebih dari 6 bulan, dengan intervensi promkes untuk menyusui menunjukkan kenaikan sampai $74 \%$ pada tahun 2010. Negara Zambia pun ada kenaikan dari hanya $20 \%$ pada tahun 1990 menjadi 60\% pada tahun 2000 (Wattimena et el., 2015). Sementara itu di Indonesia, secara nasional, angka cakupan inisiasi menyusui dini $(<1$ jam $)$ pada tahun 2013 sebesar 34,5\% (Riskesdas, 2013) dan pada tahun 2016 sebesar 42,7 \% (Pusdatin Kemenkes RI, 2017). Pada tahun 2015 cakupan pemberian ASI eksklusif sampai usia 6 bulan sebesar $55,7 \%$ (Pusdatin Kemenkes RI, 2016) dan pada tahun 2016 hanya sebesar 29,5 \% (Pusdatin Kemenkes RI, 2017). Angka keberhasilan ASI eksklusif di Indonesia secara keseluruhan cenderung menurun.

Setiap anak berhak mendapatkan ASI. Menyusui juga merupakan salah satu pengalaman paling indah yang dialami ibu dan bayi. Namun kenyataannya masih banyak ibu yang tidak menyadari pentingnya menyusui dan tidak memberikan ASI kepada anaknya. Rendahnya pengetahuan ibu tentang ASI dan status ibu yang bekerja, seringkali menjadi kendala bagi ibu untuk memberikan ASI eksklusif kepada bayinya (Perinasia, 2007). Dukungan dari berbagai pihak, mulai dari pemerintah, swasta/ dunia usaha dan 
seluruh lapisan masyarakat sangatlah penting (Pusdatin Kemenkes RI, 2017). Ibu perlu dibekali dengan pengetahuan terkaitan ASI, kiat-kiat sukses menyusui, bagaimana cara menyusui yang benar, penyimpanan ASI perah serta bagaimana manajemen pemberian ASI ketika ibu harus bekerja.

Melalui kegiatan ini, informasi mengenai berbagai hal terkait ASI dan pelatihan manajemen laktasi disosialisasikan, sesuai deklarasi Innocenti tahun 1990 di Florence Italia, anjuran WHO dan pemerintah RI yang mengamanatkan pentingnya mensosialisasikan ASI (Kemenkes RI, 2017).

\section{METODE PELAKSANAAN}

Kegiatan dilaksanakan di balai desa Karangnanas, kecamatan Sokaraja, kabupaten Banyumas. Sasaran peserta terdiri dari ibu hamil, ibu menyusui dan sejumlah perwakilan kader posyandu desa Karangnanas. Acara diawali dengan registrasi peserta, pembukaan, acara inti, dan penutupan. Acara inti kegiatan ini berupa paparan mengenai manajemen laktasi yang diawali dengan pre-test dan selanjutnya pada akhir paparan diberikan posttest. Tim membagikan lembar informed consent dan kuesioner untuk diisi. Data kuesioner dan hasil pre-test dan post-test selanjutnya dianalisis menggunakan software komputer.

Pada kegiatan ini, tim menggunakan beberapa metode untuk mentransfer pengetahuan dan keterampilan kepada para peserta dengan harapan supaya tujuan kegiatan ini dapat tercapai. Metode ceramah/ penyuluhan digunakan oleh tim untuk menyampaikan informasi mengenai segala hal terkait ASI (manfaat, ASI eksklusif, kiat sukses menyusui ), tata cara menyusui yang benar dan manajemen laktasi pada ibu bekerja. Selanjutnya melalui metode peragaan, tim memperagakan / mempraktekkan teknik menyusui yang benar. Pada metode ini tim membawa perangkat boneka (manekin) untuk mempraktekkan teknik menyusui yang baik. Selain dua metode tersebut, video berdurasi pendek diantaranya video bagaimana ASI diproduksi dan keluar dari payudara, dan video teknik menyusui yang baik diantaranya terkait posisi ibu dan bayinya serta terkait perlekatan mulut bayi dengan payudara, diperlihatkan kepada peserta pelatihan. Metode terakhir yaitu sesi konsultasi dan diskusi. Pada sesi ini, tim membuka beberapa sesi diskusi dan mempersilahkan kepada peserta untuk bertanya mengenai segala hal terkait ASI dan tumbuh kembang anak.

\section{HASIL DAN PEMBAHASAN}

Kegiatan ini merupakan kerjasama lintas sektoral di bidang kesehatan antara Fakultas Kedokteran (FK) Unsoed Purwokerto dengan Puskesmas Sokaraja 1, serta dengan jajaran pemerintahan desa Karangnanas. Dalam kesempatan ini, Kepala Puskesmas Sokaraja 1 (dr. Fajar, MM) dan Kepala Desa Karangnanas (Bapak Kuswanto WA), turut hadir dan memberikan sambutan. Ibu bidan desa (ibu Tri Yogi, A.Md) juga terlibat aktif dalam pelaksanaan kegiatan ini. Antusiasme peserta baik, terbukti dari hadirnya peserta yang memenuhi balai desa Karangnanas, sejumlah 53 orang, yang terdiri dari ibu hamil, ibu menyusui dan sejumlah perwakilan kader posyandu Karangnanas. 


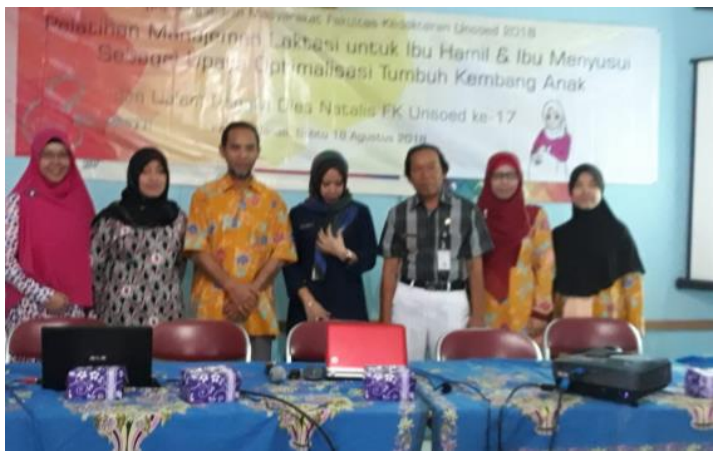

Gambar 1. Tim Pengabdi bersama Kepala Puskesmas Sokaraja 1 dan Kades Karangnanas

Pada sesi acara inti, pembicara memaparkan bahwa posisi dan perlekatan yang salah menyebabkan bayi kesulitan menetek. Hal ini seringkali memberikan kesan bahwa bayi tidak mau menyusu, bayi kesulitan menyusu, putus asa dan akhirnya menangis, sehingga orang tua sering menilai salah, bahwa bayi tidak mau meminum ASI ibunya. Hal tersebut sebenarnya merupakan masalah sederhana yang bisa diberikan solusi mudah jika posisi bayi dan khususnya perlekatan sudah benar (Perinasia, 2007). Dukungan keluarga, terutama suami, juga sangat penting dalam upaya mencapai keberhasilan menyusui. Kondisi stress pada ibu, kurang istirahat, sedih, emosi dan juga nyeri akan mempersulit proses menyusui dan mengakibatkan pengosongan ASI tidak efektif. Hal ini mengakibatkan produksi ASI tidak lancar/terganggu (Perinasia, 2007). Apabila hal tersebut tidak segera teratasi, maka keluarga hampir pasti akan memilih susu formula sebagai solusinya.

Bayi tidak beruntung (tidak mendapat ASI) dan diberikan susu formula (susu sapi) dengan kandungan nutrisi dan manfaat lain yang jauh di bawah ASI dan sering menyebabkan alergi di usia dini. Berbagai keluhan bisa terjadi akibat susu formula, diantaranya kulit alergi / kemerahan, mencret, sulit buang air besar (konstipasi), batuk, dan lain-lain. Hampir semua sistem organ tubuh terlibat dan gejala akibat alergi susu sapi antara lain pada gastrointestinal (50-60\%), kulit (50-60\%) dan sistem pernapasan (20-30\%) (IDAI, 2014; Perinasia, 2007).

Bayi yang mengalami konstipasi akan sering mengejan berlebihan berpotensi terjadi hernia umbilikalis (bodong) maupun hernia inguinalis (tedun). Susu formula juga dapat menyebabkan kejadian dehidrasi akibat diare. Selain gangguan gastrointestinal, bayi akan sering mengalami gangguan respirasi, seperti batuk, pilek dan akhirnya kelak akan menjadi penderita asma. Susu formula juga seringkali menyebabkan obesitas pada anak karena dibuat dengan volume dan frekuensi yang berlebihan (Perinasia, 2007). Konsekuensi ekonomi susu formula akan menguras keuangan keluarga bisa mencapai ratusan hingga jutaan rupiah untuk pembelian susu formula dan peralatan yang dipakai.

Semua hal tersebut terkait susu farmula jarang/tidak akan terjadi pada anak yang diberi ASI. ASI merupakan makanan bayi terbaik yang diciptakan oleh Tuhan dengan segala kelebihannya, yang tidak dapat tergantikan oleh makanan dan minuman lainnya. ASI mengandung lemak, protein, karbohidrat, vitamin, mineral, enzim, hormon dan semua nutrisi penting yang diperlukan bayi untuk tumbuh kembangnya. Tidak semua manfaat ASI dapat digantikan oleh susu buatan industri. Disamping itu, ASI mengandung zat-zat kekebalan (antibodi) dan zat penting lainnya yang melindungi anak dari infeksi dan penyakit kronis, serta mengurangi kemungkinan menderita gangguan kesehatan di kemudian hari seperti obesitas, diabetes, dan asma (Perinasia, 2007). Adanya 
faktor protektif dan nutrien yang sesuai dalam ASI diharapkan angka kesakitan dan kematian anak menurun, serta anak dapat tumbuh dan berkembang secara optimal sesuai harapan orangtua. Pemberian ASI juga merupakan wujud kasih sayang ibu terhadap sang buah hati. Menyusui dapat menciptakan ikatan psikologis dan kasih sayang yang kuat antara ibu dan bayi. Pemberian ASI merupakan kunci peningkatan kualitas manusia Indonesia.

Kegiatan ini diikuti oleh 53 peserta, yang terdiri dari ibu hamil dan ibu menyusui, serta sejumlah kader posyandu desa Karangnanas. Usia peserta termuda 17 tahun, dan paling tua 77 tahun. Peserta terbanyak berada dalam rentang usia 30-40 tahun, dengan rerata usia peserta 36,68 $\pm 11,26$ tahun. Peserta usia $>50$ tahun merupakan kader kesehatan di desa Karangnanas.

Tingkat pendidikan peserta pelatihan bervariasi, mulai dari SD (11\%), SMP (53 \%), SMA (28 \%), dan Sarjana (7\%). Sebagian besar peserta merupakan ibu rumah tangga (75\%), selebihnya adalah karyawan (15\%), pedagang (8\%) dan guru (2\%). Sejumlah 60,4 $\%$ peserta pelatihan menyebutkan sudah pernah mendapatkan info mengenai ASI sebelumnya, dimana info diperoleh dari tenaga kesehatan (bidan setempat), ketika melakukan pemeriksaan kehamilan. Diantara peserta yang hadir, sebanyak $54,1 \%$ peserta pernah memberikan ASI eksklusif 6 bulan, $27 \%$ peserta memberikan ASI eksklusif selama 4 bulan, dan lainnya 2-3 bulan. Sebagian besar peserta $(87,5 \%)$ tidak memberikan empeng pada anak. Angka cakupan ASI eksklusif ini berbeda (berbanding terbalik) dengan penelitian yang dilakukan oleh Dwinanda et al. (2018), dimana pada penelitian tersebut, cakupan ASI eksklusif 6 bulan, 5 bulan, 4 bulan, 3 bulan, 2 bulan, dan 1 bulan berturutturut sebesar 22,3\%, 23,5\%, 30,7\%, 43\%, 53,7\%, dan 64,8\%. Hal ini kemungkinan disebabkan oleh perbedaan karakteristik subyek penelitian. Pada penelitian kami, sebagian besar subyek merupakan ibu rumah tangga, sedangkan penelitian Dwinanda et al. (2018) tersebut 70\% merupakan ibu bekerja.

Selain pembagian kuesioner, sebelum dan setelah kegiatan inti penyuluhan dan pelatihan, peserta juga diberikan soal pre-test dan post-test. Nilai pre-test peserta didapatkan rerata $49,02 \pm 19,74$, dengan nilai terendah 0 dan nilai tertinggi 83 . Sementara itu nilai post-test peserta didapatkan rerata 68,53 $\pm 20,00$; dengan nilai terendah 17 dan nilai tertinggi 100. Nilai peserta tidak terdistribusi normal, hasil uji statistik dengan Wilcoxon Rank Test menunjukkan adanya perbedaan signifikan antara nilai pre-test dan post-test, dengan $p=0,000$. Hal ini menunjukkan bahwa kegiatan ini dapat meningkatkan pengetahuan peserta secara signifikan mengenai manajemen laktasi.

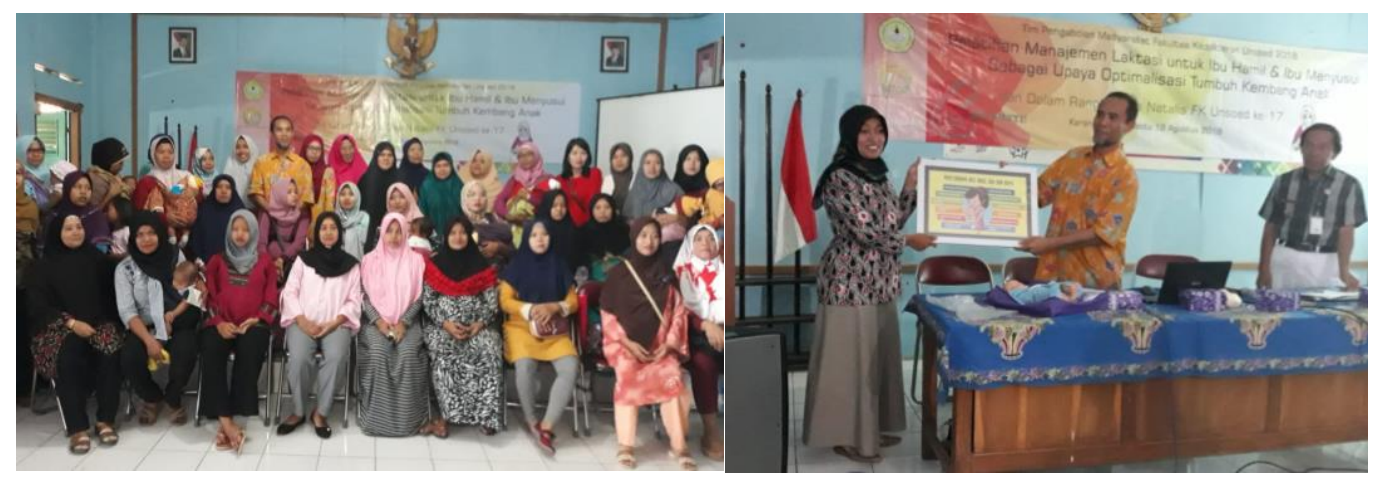

Gambar 2. Tim Pengabdi bersama dengan Peserta Pelatihan 


\section{SIMPULAN}

Kegiatan ini dapat meningkatkan pengetahuan peserta pelatihan secara signifikan, mengenai ASI, tatacara/bagaimana menyusui yang baik dan benar, serta bagaimana manajemen pemberian ASI ketika ibu harus bekerja. Melalui kegiatan ini juga diperoleh data karakteristik peserta pelatihan.

\section{REFERENSI}

Besar, D. S., \& Eveline, P. N. (2008). Air susu ibu dan hak bayi. Dalam B. Hegar, R. Suradi, A. Hendarto, \& I. G. A. Partiwi (Eds.), Bedah ASI. Jakarta: IDAI (pp. 1-16).

Dwinanda, N., Syarif, B.H., \& Sjarif, D. R. (2018). Factors affecting exclusive breasfeeding in term infants. Paediatrica Indonesiana. 58(1), 25-35.

Fahriani, R., Rohsiswatno, R., Hendarto, A. (2014). Faktor yang mempengaruhi pemberian asi eksklusif pada bayi cukup bulan yang dilakukan inisiasi menyusu dini (IMD). Sari Pediatri. 15(6), 394-402.

Hegar, B. (2010). Nilai menyusui. Dalam R. Suradi, B. Hegar, I. G. A. Partiwi, A. N. Marzuki, \& Y. Ananta (Eds.). Indonesia menyusui. 1 st ed. Jakarta: IDAI, (pp. 1-12).

Ikatan Dokter Anak Indonesia. (2009). Air Susu dan Tumbuh Kembang. Jakarta: IDAI.

Ikatan Dokter Anak Indonesia. (2014). Rekomendasi Ikatan Dokter Anak Indonesia: Diagnosis dan Tata Laksana Alergi Susu Sapi. Jakarta: IDAI.

Irwandi, I., Lubis, G., \& Lipoeto, N. I. (2018). Perbedaan kadar lisozim dalam air susu ibu (ASI) pada bayi sehat dan bayi sakit yang mendapat ASI eksklusif. Sari Pediatri, 19(5), 273-278.

Kementerian Kesehatan Republik Indonesia [Kemenkes RI]. (2017). Pedoman Penyelenggaraan Pekan ASI sedunia (PAS) 2017. Jakarta: Kemenkes RI.

Perkumpulan Perinatologi Indonesia (Perinasia). (2007). Panduan peserta pelatihan konseling menyusui: Modul 40 jam standar WHO/UNICEF/KEMKES. Jakarta: Perinasia.

Permatasari, T.A.E. (2012). Istimewakah air susu ibu secara islam dan kesehatan? Jurnal Kedokteran dan Kesehatan, 8(1), 55-68.

Pusat Data dan Informasi Kementerian Kesehatan RI. (2017). Profil Kesehatan Indonesia 2016. Jakarta: Pusdatin Kemenkes RI.

Pusat Data dan Informasi Kementerian Kesehatan RI. (2016). Profil Kesehatan Indonesia 2015. Jakarta: Pusdatin Kemenkes RI.

Riskesdas. (2013). Riset Kesehatan Dasar 2013. Badan Penelitian dan Pengembangan Kesehatan Kementerian Kesehatan RI. Jakarta: Kementerian Kesehatan RI.

Suradi, R. (2007). Manajemen laktasi. Dalam R. Suradi \& H. K. Tobing (Eds.). Jakarta: Perinasia, (pp. 1-5).

Wattimena, I., Werdani, Y. D. W., Novita, B. D., \& Dewi, D. A. (2015). Manajemen laktasi dan kesejahteraan ibu menyusui. Jurnal Psikologi UGM, 42(3), 231-242.

World Health Organization [WHO]. (2014). Global nutrition targets 2025: Breastfeeding policy brief (No. WHO/NMH/NHD/14.7). Jenewa: World Health Organization. 